\title{
FIVE DEPICTIONS OF THE CIRCUMCISION OF JESUS CHRIST FROM THE CROATIAN SACRAL HERITAGE
}

\author{
PET PRIMJERA OBREZANJA ISUSA KRISTA IZ \\ HRVATSKE SAKRALNE BAŠTINE
}

\author{
Tatjana Čulina*
}

\begin{abstract}
SUMMARY
Male circumcision has been perceived differently in different cultures. In modern times, if it is a non-medical indication, circumcision becomes the starting point of many ethical and other discussions. Its rootedness in Christianity is fixed, among other things, in sacral art and iconography. This article presents five sacral images of the Circumcision of Christ from the holdings of the Croatian sacral heritage with the aim of noticing their iconographic and sacral-medical values. In this article, it is presented the results of field research related to the identification and medical-iconographic presentation of the motive for the circumcision of Jesus Christ in the area of the northern and central Adriatic coast. Five such paintings have been recorded and will be described and compared with similar works by European masters. These are the works of Venetian and Central European provenance and were created between the $\mathrm{I}^{\text {th }}$ and $18^{\text {th }}$ centuries. The basic traditional Jewish iconography is visible in all the paintings but modified according to current religious standards. These depictions from the area of Croatia contextualizing and filling in the gaps in verbal records on this topic in our region fit Croatia into an undoubted component of the European Judeo-Christian heritage and when it comes to rare iconographic depictions.
\end{abstract}

Keywords: history of medicine, circumcision, religion, medicine in art, Croatia, $16^{\text {th }}$ to $18^{\text {th }}$ centuries

* Correspondence Address: Katedra za obiteljsku medicinu, Medicinski fakultet, Sveučilište u Rijeci, Braće Branchetta 20, 51000 Rijeka. E-mail: golubica2@yahoo.com. ORCID ID: https:// orcid.org/0000-0001-5404-8761. 


\section{INTRODUCTION}

Although circumcision has been known since ancient times, primarily a surgical procedure for removing the foreskin on the male genitalia, it still has its supporters, but also opponents, its popularity trends, all sorts of explanations and motivation. ${ }^{1,2,3,4}$

From the writings contained in the Bible, Herodotus' chronicles, medical manuscripts, and other sources, we learn that this procedure gained and lost in popularity. It mainly grows out of traditional, mostly religious beliefs, often intertwined with attitudes related to hygienic and preventive measures. ${ }^{5,6}$ Jesus, whose circumcision is the subject of this account, was circumcised because he was a child born of the seed of Abraham. ${ }^{7}$ His parents were devoted Jews and brought him to be circumcised on the eighth day, and then under the Levitical Code went through the requirements of purification. Circumcision was a command from God to distinguish his people from the Gentiles. A circumcised child means that he belongs to God and becomes a recipient of covenant promises. ${ }^{8}$

Two important moments stand out in this ritual process: the first shedding of Christ's blood and his first suffering, and the first of the seven sorrows of the Mother of God and the naming of Jesus.

According to the rules of the law of Moses, Christ was circumcised on the eighth day after his birth, and like every Jew, a man was given a name during circumcision. The evangelist Luke describes it this way: And when eight days

1 Clark, Peter A. (2006), To circumcise or not to circumcise. A Catholic ethicist argues that the practice is not in the best interest of male infants, Health Progress, 87(5), 30.

2 Zampieri, Nicola, Pianezzola, Emanuela, Zampieri, Cecilia (2008), Male circumcision through the ages: the role of tradition, Acta paediatrica. (2008). 97(9):1305

3 Dekkers, Wim (2009), Routine neonatal circumcision and bodily integrity: a transatlantic dialogue, The Kennedy Institute of EthicsJournal, 19(2),125. DOI: 10.1353/ken.0.0279

4 Crawford, Doreen Anne (2002), Circumcision: A Consideration of Some of the Controversy, Journal of Child Health Care, 6(4), 259-70. DOI: https://doi.org/10.1177/136749350200600403

5 Di Pietro, Maria Luisa, Teleman, Adele A., Poscia, Andrea, González-Melado, Fermín J., Panocchia, Nicola (2017), Preventive Newborn Male Circumcision: What Is the Child's Best Interest?Cuadernos de Bioetica, 28(94), 303.

6 Fink, Kenneth S., Carson, Culley C., DeVellis, Robert S. (2002), Adult Circumcision Outcomes Study: Effect on Erectile Function, Penil sensitivity, Sexual Activity and Satisfaction, Journal of Urology, 167, 2113.

Ibid, 2113.

8 Leviticus 12. New International Version (1978), https:// ww.biblegateway.com/passage/?search= Genesis\%2017\&version=NIV (accessed: 6 December 2020). 
were accomplished for the circumcising of the child, his name was called Jesus, which was so named of the angel before he was conceived in the womb. ${ }^{9,10}$

This is also evident from the dialogue between God and Abraham, the first circumcised Jewish patriarch, described in the Book of Genesis: ..."You are to undergo circumcision, and it will be the sign of the covenant between me and you. For generations to come every male among you who is eight days old must be circumcised, including tho-se born in your household or bought with money from a foreigner - those who are not your offspring. Whether born in your household or bought with your money, they must be circumcised. My covenant in your flesh is to be an everlasting covenant. Any uncircumcised male, who has not been circumcised in the flesh, will be cut off from his people; he has broken my covenant." 11

\section{ICONOGRAPHY OF CIRCUMCISION IN THE CROATIAN TRADITION}

Circumcision of men is the oldest surgical procedure that has always been motivated by traditional and religious aspects. According to Jewish law, it is a symbol of the agreement between God and Abraham and is considered the beginning of the entry of male children into the Jewish faith. The procedure is part of a solemn act that takes place in the circle of family and friends. Until the $19^{\text {th }}$ century, circumcision was a symbol of religious or other cultural identities. This aspect determined the frequency of circumcision in an area, the place, the person, and the manner and time of performance and was not ne-

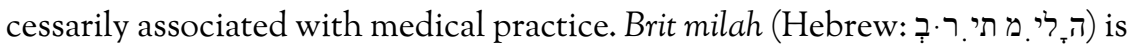
a Jewish religious ritual of circumcision of a male newborn at the age of eight days. It is customary for the brit to be held in the synagogue, but it may also be held in any other suitable place. Parents and relatives usually take part in the ritual with the newborn. As a rule, there are also two officially authorized persons. The first is the mohel, and the second is the quarter, i.e., the person who takes the child from the mother and carries it to the father, and he will hand it over to the mohel to perform the rite of circumcision. ${ }^{12}$

9 Gospel, Lc 2, 21. New international Version (1978),https://www.biblegateway.com/passage/?search $=$ Luke\%202:21\&version=NIV (accessed: 6 August 2020).

10 Mattelaer, Johan J.,Schipper, Robert A., Das, Sakti (2007), The circumcision of Jesus Christ, Journal of Urology, 178(1), 31. DOI: 10.1016/j.juro.2007.03.016.

11 Gospel, Genezis 17, 11-14. New International Version (1987), https:// ww.biblegateway.com/passage $/$ ?search $=$ Genesis\%2017 \&version $=$ NIV (accessed: 6 August 2020).

12 Circumcision of Jesus Christ, https: //www.google.com/search? q=circumcis ion +of + jesus \&safe = active \&sxsrf $=$ LeKk02NKihgFdJM9HZfqwsjg_Lvm710kA:1596300067338\&source $=\operatorname{lnms} \& \quad \mathrm{tbm}=\mathrm{isch} \& \mathrm{sa}=\mathrm{X} \& \mathrm{ved}=2 \mathrm{ahUKEwj} 2 \mathrm{zN}-\mathrm{ufrqAhXGiVwKHQobiw}=991 \& b i$ $\mathrm{h}=714$ (accessed: 6 August 2020). 
Basic Christian iconography and costume design remain in all Christian paintings but have been modified according to current religious standards. In addition to the naked Child, the high priest and one or two assistants in the function of the Jewish mohel and quarter, who lead the rite, must be present. In most cases, one of them holds a ritual knife of different shape and size. The number and function of the other participants alongside Mary and Joseph vary from a few to a diverse crowd. While relatively few paintings from the Middle Ages have been preserved, their number and variety of depictions have been steadily increasing since the Renaissance. ${ }^{13}$

\section{Material ANd Methods}

This articlepresents the results of field research related to the identification and medical-iconographic presentation of the motives for the circumcision of Jesus Christ in the area of the northern and central Adriatic coast. Five such paintings have been recorded and will be described and compared with similar works by European masters. ${ }^{14}$ They were created in the period from the middle of the $16^{\text {th }}$ to the $18^{\text {th }}$ century, and today they are located in: Labin, Trsat (Rijeka), Košljun (island of Krk), Trogir and Split.

Before the iconographic analysis of these depictions of the circumcision of Christ, it should be remembered that they were made by Christian painters who apparently did not fully know the original Jewish procedure and therefore did not know how to present it faithfully. On the other hand, and more importantly, it was not appropriate to present an infidel rite in the context of Christian iconography.

\section{RESUlTS}

\section{Display OF SELECTED IMAGES}

The first and oldest painting in the selection is a work found in $1535-$ painted by the famous Girolamo da Santa Croce. It is part of a polyptych on the main altar of the Church of the Annunciation on the islet of Košljun near Punat on the island of Krk. ${ }^{15}$ Like the other paintings in the Polyptych, this

13 Brit milah (2005), https://en.wikipedia.org/wiki/Brit_milah. (accessed: 6 August 2020).

14 Pust, R. A., Drost, C., Willerding, H., Bschleipfer, T. (2005), Medieval scenes of ritual circumcision as a reflection of sociopolitical circumstances [In German], Urologe, 44(3), 277. DOI: 10.1007/s00120-004-0761-9.

15 Valković, J. (1995). Conventus Franciscanus Košljun[In Croatian], Košljun; Franjevački samostan, 7. 
painting is of a smaller format. The action takes place in a Renaissance festive ambience with a special table covered with a white tablecloth on which an ordinary knife is ready for the ceremony. Unlike most similar images, only a few participants are present here. The main special feature is Mary, who exceptionally, in the middle of the frame, holds the Child and hands him over to the side-placed high priest - the mohel. This is usually done by the father and the quartermaster, who are in the background here. The father is on the side of the table, and the quarter is behind the high priest.

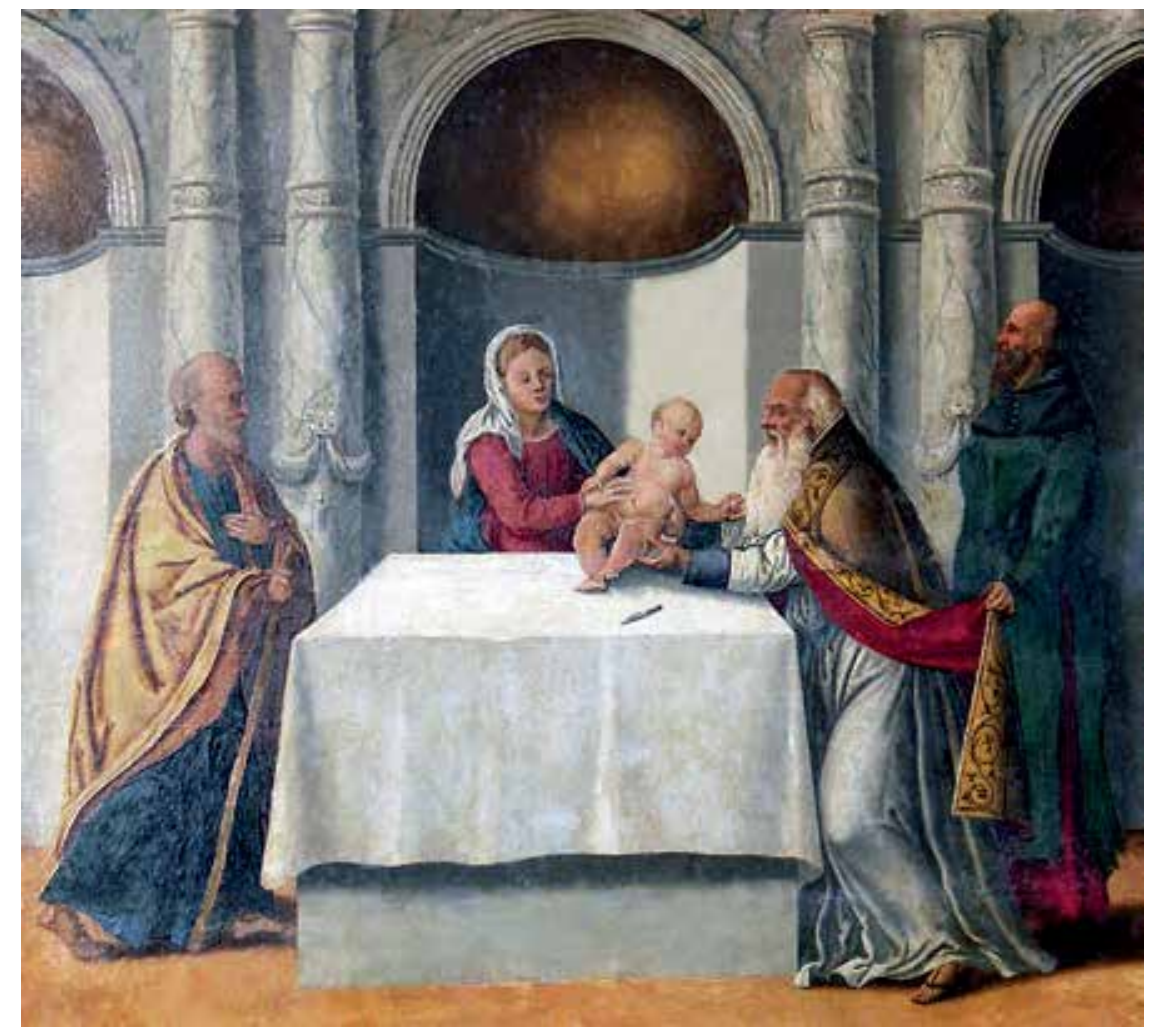

Figure r. Circumcision of Jesus. Girolamo da Santa Croce, 1535, a detached detail from a polyptych on the main altar of the Church of the Annunciation on the island of Košljun near Punat on the island of Krk.

Slika I. Obrezanje Isusa Krista. Girolamo da Santa Croce, 1535. Detalj s poliptiha na glavnom oltaru crkve Navještenja na otoku Košljunu kod Punta na otoku Krku

The second painting was painted by Jacopo Palma Jr. in I607 and is located in the Church of St. Dominica in Trogir. In the centre, next to the table, a quarter brings the Child to the mohel, who holds in his hand, like a lance, an 
elegant pruning knife. Opposite them stands Mary in prayer. In the background, there are several undefined extras, and in front, in the lower part of the picture, two Dominicans are praying devoutly.

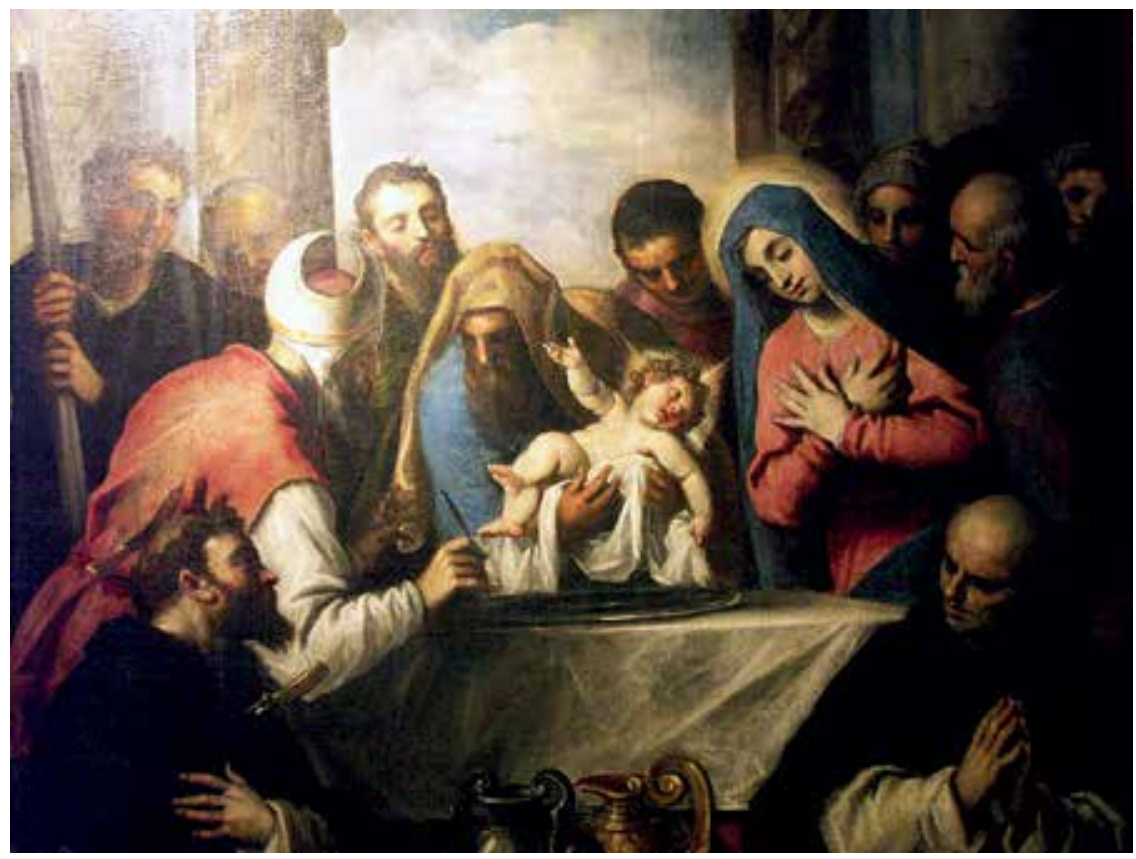

Figure 2. Circumcision of Christ, detail. Jacopo Palma Jr. 1607. Church of St. Dominika, Trogir.

Slika 2. Obrezanje Krista, detalj. Jacopo Palma Ml., I6o7. Crkva Sv. Dominika, Trogir

The third painting was found in the monastery of St. Catherinein Split. It was created in the $17^{\text {th }}$ century by a probable Venetian painter Pietro Mera (1570-I644). In this close-up picture,the high priest is holding a Child with outstretched legs ready for the procedure on a convenient table. Opposite them, a lower priest or monk, with a knife in his hand, performs the procedure. In the background, the third participant in the rite reads an appropriate text, and Mary prays. It is interesting to mention that this painter is the author of another similarly conceived painting with the same theme. ${ }^{16}$

16 Mera, Pietro (1570 - 1664), Circoncisione, https://commons.wikimedia.org/wiki/File:Interior_of_Santi_Giovanni_e_Paolo_(Venice)__Circoncisione_by_Pietro_Mera.jpg (accessed: 20 December 2020). 


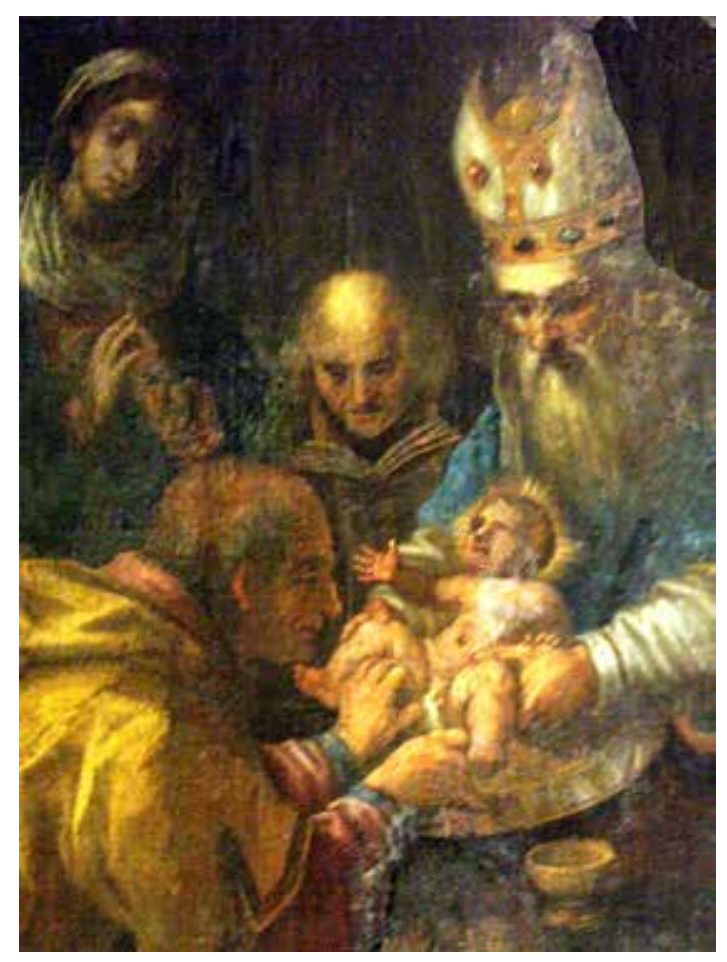

Figure 3. Circumcision of Christ. Pietro Mera (?), $17^{\text {th }}$ century. Monastery of St. Katarine, Split.

Slika 3. Obrezanje Krista. Pietro Mera (?), 17. st. Samostan sv. Katarine, Split

The fourth example is the wall painting in the cycle Life of the Mother of God in the Franciscan Monastery of the Shrine of the Mother of God on $\mathrm{Tr}$ sat in Rijeka. It was painted by Fr. Serafin Schön, around I63I and I6 35 . He is a Franciscan painter of Swiss origin who spent part of his life in Trsat. He was formed as a painter under the influence of Paolo Piazza, a Venetian Capuchin and painter who worked in Central Europe, and the Bavarian painter Hans Rottehnammer. ${ }^{17}$

In the close-up of the semicircular wall painting, there is a high priest with a Child who follows the situation with a clear eye (?). One of the two assistants stands sideways with a large knife, ready for the procedure. The scene is supervised by St. Joseph, and Mary is comforted by a friend in the background.

17 Kudiš, Nina (1997), Notes on the oeuvre of Serafin Schon [In Croatian], Peristil: zbornik radova za povijest umjetnosti, $40(1), 81$. 


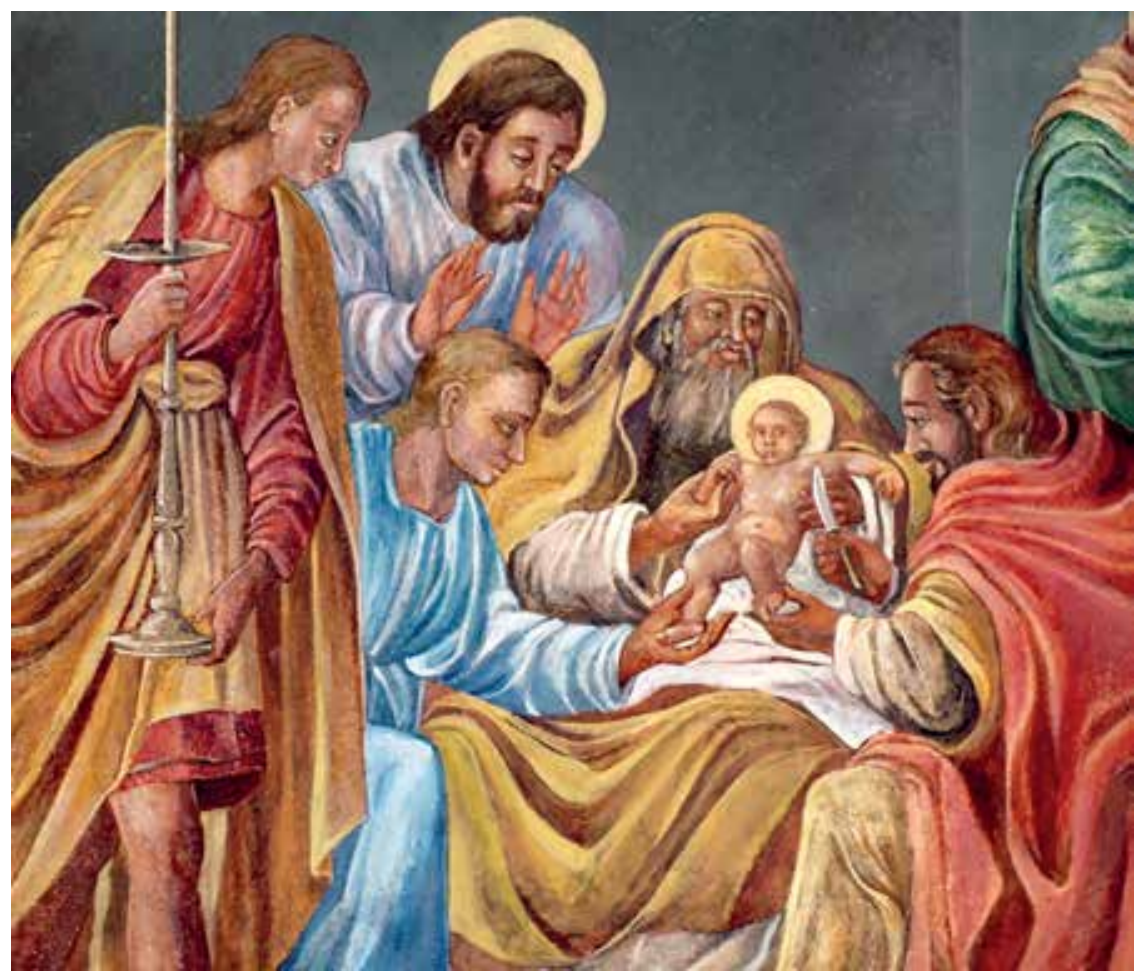

Figure 4. Circumcision of Jesus. Serafin Schön, circa I630, wall painting in the cycle Life of Mother of God. Franciscan monastery of the Shrine of the Mother of God on Trsat in Rijeka.

Slika 4. Obrezanje Isusa. Serafin Schön, oko i63o. Zidna slika iz ciklusa Život Majke Božje. Franjevački samostan Svetišta Majke Božje na Trsatu u Rijeci

Since he is a Central European educated artist, this is an appropriate association with similar works from, e.g., Albrecht Dürer (I47I-I528), ${ }^{18}$ and the larger knife in the painting by Serafin Schön is reminiscent of a frighteningly large knife by Fridrich Herlin (I430- 1500). ${ }^{19}$

The fifth painting presented on this occasion is part of an altar triptych by an unknown author from the $18^{\text {th }}$ century in the parish church in Labin in Istria. In the sumptuous baroque staging, with numerous spectators, in the centre is an appropriate table on which one of the two assistants holds the

18 Dürer, A. (1471 - 1528), Circumcision of Christ, httpsreligioncatolicaromana.blogspot.com201405circuncision-significado-definicion.html (accessed: 6 August 2020).

19 Herlin, F. (1430 - 1500), Circumcision of Jesus, httpsen.wikipedia.orgwikiCircumcision_of_Jesus\#mediaFileCirconcisionRothenburg.jpg (accessed: 6 August 2020). 
Child, and the high priest prepares for the intervention with a small knife. Thanks to the number of extras and, above all, the rich staging, this presentation, as well as the entire triptych, belong to the group of younger examples in which earlier Renaissance experiences were completed. Among the presented paintings, this is certainly the most lavish, and of the world-famous reminiscent of Tintoretto's depiction of circumcision. ${ }^{20}$

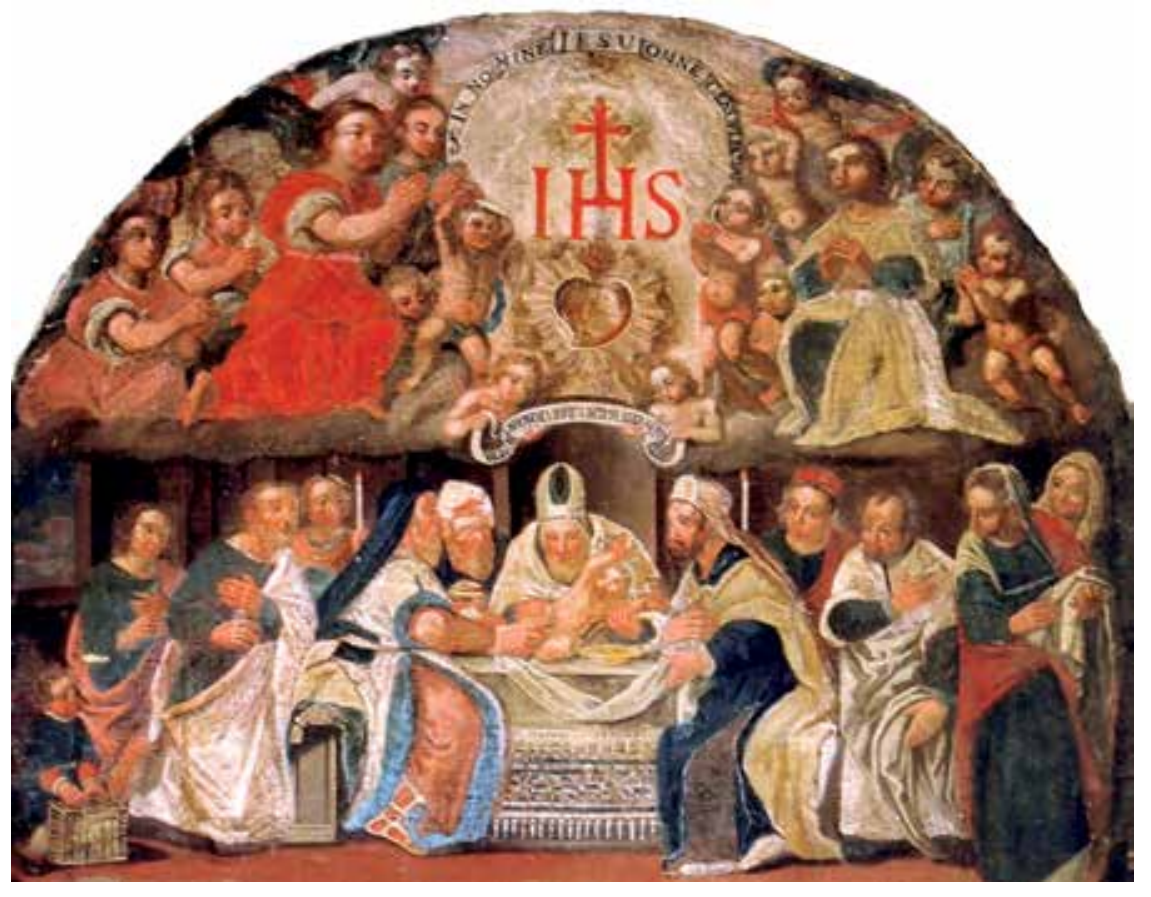

Figure 5. Circumcision of Jesus. Unknown author, $\mathrm{I}^{\text {th }}$ century. Part of the triptych Celebrating the Name of Jesus. Parish Church in the Circumcision of Christ, Labin.

Slika 5. Obrezanje Isusa. Nepoznati autor, 18. st. Dio triptiha Slavljenje Isusova imena. Župna crkva Isusova obrezanja, Labin

The authors and the presented paintings are part of the Venetian and Central European painting traditions from the $16^{\text {th }}$ to the $18^{\text {th }}$ century.

20 Tintoretto (1518-1594),Circumcision, httpssh.wikipedia.orgwikiScuola_Grande_di_San_Rocco\#media DatotekaTintoretto-Circumcision.jpg (accessed: 6 August 2020). 


\section{DiscUSSION AND CONCLUSION}

Works that deal with cultural determinants of attitudes and attitudes related to the topic of circumcision of men are extremely rare in Croatia. Some authors connect this with the specifics of the socio-political framework of the second half of the $20^{\text {th }}$ century, within which certain topics did not meet the wider interest of researchers. ${ }^{21}$ Equally rare are studies related to parental knowledge of child circumcision, and the first such study was conducted recently. The conclusion reached by the authors is that the knowledge of parents about the circumcision of male children is not adequate and that it requires better information and education, especially for mothers and parents from rural areas. ${ }^{22}$

In the context of the development of close European countries, Croatian science, art, and medicine also developed. There is a great coincidence with the circumstances in the neighbouring Italian and Central European regionsregarding the appearance of sacral art. In this sense, the research that brings results related to the presence of medical elements in sacral art in Croatia is valuable. $^{23,24,25}$ It can be seen from them that there are topics that are more frequent and more frequently represented in both Croatian and European sacral art, such as depictions of the birth of Jesus, depictions of individual saints in the populace, especially protectors from disease. ${ }^{26}$ The view of St. Rochus and St. Sabastian as protectors against plague and other epidemics are topics that reflect helplessness and fear of death. ${ }^{27}$ It was mostly painted what made people happy or sad and what people recognised as their reality. In contrast, sacral representations of circumcision are part of relatively small holdings of the themes of the Circumcision of Jesus Christ in Christian sacral art in general. This is understandable considering the religious content

21 Hromadko, Miroslav, Fatović-Ferenčić, Stella (2007), Circumcision: cultural entity and medical controversy. [In Croatian], Liječnički Vjesnik, 129(6-7), 241.

22 Puharić, Zrinka, Tomljanović, Ksenija, Puharić, Filip, Žulec, Mirna, Grabovac, Đurđica (2019), Parents' knowledge of circumcision, Acta Medica Croatica, 73(4), 387.

23 Škrobonja, Ante, Kontošić, Ivica, Muzur, Amir (1999), Conception and pregnancy in several examples from Croatian sacral patrimony, European Journal of Obstetrics \& Gynaecology and Reproductive Biology, 85, 215.

24 Škrobonja, Ante, Muzur, Amir, Kontošić, Ivica (1999), Birth of St. Mary (St. Anne's parturition) in the light of the medical education. Some examples from Croatian sacral art, Journal of Perinatal Medicine, 27, 417-422. DOI: 10.1515/jpme.1999.27.6.417.

25 Škrobonja, Ante, Muzur, Amir, Škrobonja, Ante Jr. (2003), Two examples of reimplantation from Croatian sacral patrimony, Annals of Plastic Surgery, 50, 412. DOI: 10.1097/01. SAP.0000042147.61015.C8.

26 Škrobonja, Ante (2003). Saints of health. [In Croatian], Zagreb; Kršćanska sadašnjost.

27 Muzur, Amir, Škrobonja, Ante (1995), Plague, cholera and the cult of St. Roch in Istria - parallels. [In Croatian], Medicus, 4, 207-215. 
of the topic and its visualisation within which the focus is on the naked child, the boy's genitals, and bloody surgery.

Not only has this topic been sporadically researched in our area, but this fact stems from the scarcity of sources related to the description of circumcision for the Croatian early, medieval, but also later periods. The shortcoming in written sources is somewhat overcome in the field of art $^{28}$ and more recent unofficial sources. ${ }^{29}$ To that extent, these depictions from the area of Croatia, contextualising and filling in the gaps in verbal records on this topic in our region, fit Croatia into an undoubted component of the European Judeo-Christian heritage and when it comes to rare iconographic depictions.

28 Fučić, Branko (1990), Circumcision of Christ, In: Badurina Anđelko ed., Lexicon of iconography, liturgy, and symbolic of Western Christianity. [In Croatian], Zagreb: Kršćanska sadašnjost, 431.

29 Church art in Croatia (In Croatian) (2020), https://hr.wikipedia.org/wiki/Crkvena_umjetnost_u_Hrvatskoj (accessed: 6 August 2020). 


\section{LITERATURE AND SOURCES}

1. Brit milah (2005),https://en.wikipedia.org/wiki/Brit_milah. (accessed: 6 August 2020).

2. Church art in Croatia (In Croatian) (2020), https://hr.wikipedia.org/wiki/Crkvena_ umjetnost_u_Hrvatskoj (accessed: 6 August 2020).

3. Circumcision of Jesus Christ, https: //www.google.com/search? q= circumcis ion + of + jesus\&safe $=$ active $\&$ sxsrf $=$ LeKk02NKihgFdJM9HZfqwsjg_Lvm710kA:159630 $0067338 \&$ source $=\operatorname{lnms} \&$ tbm $=$ isch $\&$ sa $=X \& v e d=2$ ahUKEwj2zN-ufrqAhXGiVwK HQobiw $=991 \& b i h=714$ (accessed: 6 August 2020).

4. Clark, Peter A. (2006), To circumcise or not to circumcise. A Catholic ethicist argues that the practice is not in the best interest of male infants, Health Progress, 87 (5), 30.

5. Crawford, Doreen Anne (2002), Circumcision: A Consideration of Some of the Controversy, Journal of Child Health Care, 6(4), 259-70. DOI: https://doi. org/10.1177/136749350200600403

6. Dekkers, Wim (2009), Routine neonatal circumcision and bodily integrity: a transatlantic dialogue, The Kennedy Institute of EthicsJournal, 19(2),125. DOI: 10.1353/ ken.0.0279

7. Di Pietro, Maria Luisa, Teleman, Adele A., Poscia, Andrea, González-Melado, Fermín J., Panocchia, Nicola (2017), Preventive Newborn Male Circumcision: What Is the Child's Best Interest? Cuadernos de Bioetica, 28(94), 303.

8. Dürer, A. (1471-1528), Circumcision of Christ, httpsreligioncatolicaromana.blogspot. com201405circuncision-significado-definicion.html (accessed: 6 August 2020).

9. Fink, Kenneth S., Carson, Culley C., DeVellis, Robert S. (2002), Adult Circumcision Outcomes Study: Effect on Erectile Function, Penil sensitivity, Sexual Activity and Satisfaction, Journal of Urology, 167, 2113.

10. Fučić, Branko (1990), Circumcision of Christ, In: Badurina Anđelko ed., Lexicon of iconography, liturgy, and symbolic of Western Christianity. [In Croatian], Zagreb: Kršćanska sadašnjost, 431.

11. Gospel, Genezis 17, 11-14. New International Version (1987), https:// ww.biblegateway. $\mathrm{com} /$ passage $/$ ?search $=$ Genesis\%2017\&version =NIV (accessed: 6 August 2020).

12. Gospel, Lc 2, 21. New international Version (1978),https://www.biblegateway.com/passage/?search=Luke\%202:21\&version=NIV (accessed: 6 August 2020).

13. Herlin, F. (1430 - 1500), Circumcision of Jesus, httpsen.wikipedia.orgwikiCircumcision_of_Jesus\#mediaFileCirconcisionRothenburg.jpg (accessed: 6 August 2020).

14. Hromadko, Miroslav, Fatović-Ferenčić, Stella (2007), Circumcision: cultural entity and medical controversy. [In Croatian], Liječnički Vjesnik, 129(6-7), 241.

15. Kudiš, Nina (1997), Notes on the oeuvre of Serafin Schon [In Croatian], Peristil: zbornik radova za povijest umjetnosti, 40(1), 81.

16. Leviticus 12. New International Version (1978), https:// ww.biblegateway.com/passage/?search $=$ Genesis\%2017\&version=NIV (accessed: 6 December 2020).

17. Mattelaer, Johan J.,Schipper, Robert A., Das, Sakti (2007), The circumcision of Jesus Christ, Journal of Urology, 178(1), 31. DOI: 10.1016/j.juro.2007.03.016.

18. Mera, Pietro (1570 - 1664), Circoncisione, https://commons.wikimedia.org/wiki/File:Interior_of_Santi_Giovanni_e_Paolo_(Venice)__Circoncisione_by_Pietro_Mera. jpg (accessed: 20 December 2020). 
19. Muzur, Amir, Škrobonja, Ante (1995), Plague, cholera and the cult of St. Roch in Istria - parallels. [In Croatian], Medicus, 4, 207-215.

20. Puharić, Zrinka, Tomljanović, Ksenija, Puharić, Filip, Žulec, Mirna, Grabovac, Đurđica (2019), Parents' knowledge of circumcision, Acta Medica Croatica, 73(4), 387.

21. Pust, R. A., Drost, C., Willerding, H., Bschleipfer, T. (2005), Medieval scenes of ritual circumcision as a reflection of sociopolitical circumstances [In German], Urologe, 44(3), 277. DOI: 10.1007/s00120-004-0761-9.

22. Škrobonja, Ante (2003). Saints of health. [In Croatian], Zagreb; Kršćanska sadašnjost.

23. Škrobonja, Ante, Kontošić, Ivica, Muzur, Amir (1999), Conception and pregnancy in several examples from Croatian sacral patrimony, European Journal of Obstetrics \& Gynecology and Reproductive Biology, 85, 215.

24. Škrobonja, Ante, Muzur, Amir, Kontošić, Ivica (1999), Birth of St. Mary (St. Anness parturition) in the light of the medical education. Somme examples from Croatian sacral art, Journal of Perinatal Medicine, 27, 417-422. DOI: 10.1515/jpme.1999.27.6.417.

25. Škrobonja, Ante, Muzur, Amir, Škrobonja, Ante Jr. (2003), Two examples of reimplantation from Croatian sacral patrimony, Annals of Plastic Surgery, 50, 412. DOI: 10.1097/01.SAP.0000042147.61015.C8.

26. Tintoretto (1518-1594),Circumcision, httpssh.wikipedia.orgwikiScuola_Grande_di_ San_Rocco\#media DatotekaTintoretto-Circumcision.jpg (accessed: 6 August 2020).

27. Valković, J. (1995). Conventus Franciscanus Košljun [In Croatian], Košljun; Franjevački samostan, 7.

28. Zampieri, Nicola, Pianezzola, Emanuela, Zampieri, Cecilia (2008), Male circumcision through the ages: the role of tradition, Acta paediatrica. (2008). 97 (9):1305 


\section{SAŽETAK}

Obrezivanje muškaraca u različitim je kulturama različito percipirano. U suvremenosti, ako je riječ o nemedicinskoj indikaciji, cirkumcizija postaje polazištem mnogih etičkih $i$ drugih rasprava. Njezina ukorijenjenost $u$ kršćanstvu fiksirana je, između ostalog, i u sakralnoj umjetnosti i ikonografiji. U ovom radu prikazano je pet sakralnih slika Obrezanje Krista iz fundusa hrvatske sakralne baštine s ciljem uočavanja njihovih ikonografskih i sakralno-medicinskih vrijednosti. Djela su venecijanske i srednjoeuropske provenijencije, a nastala su u razdoblju od I6. do I8. stoljeća. Na svim je slikama vidliiva i osnovna tradicionalna židovska ikonografija, ali modificirana prema aktualnim vjerskim standardima. Sakralni prikazi ove tematike upotpunjuju praznine u verbalnim zapisima o ovoj tematici i njezinim simboličkim $i$ drugim značenjima na hrvatskim prostorima.

Ključne riječi: povijest medicine, obrezanje, religija, medicina u umjetnosti, Hrvatska, I6. do I8. stoljeće 